\title{
Protein Synthesis and Degradation during the Differentiation Cycle of Rhodomicrobium vannielii Swarmer Cells
}

\author{
By DAVID PORTER AND CRAWFORD S. DOW* \\ Department of Biological Sciences, University of Warwick, Coventry, CV4 7AL,UK
}

(Received 24 November 1986)

\begin{abstract}
Rhodomicrobium vannielii swarmer cells, when synchronized by selective filtration, differentiate synchronously with the loss of motility and synthesis of a prostheca, and subsequently form a daughter cell. Synchronized swarmer cells synthesized an $11.5 \mathrm{kDa}$ protein under dark anaerobic conditions which disappeared from the soluble fraction when the culture was subsequently incubated in the light and the differentiation cycle thus initiated. The protein did not accumulate under dark aerobic conditions and it may play a role in the inhibition of differentiation in the light limited and thus energy limited swarmer cell.
\end{abstract}

\section{INTRODUCTION}

Rhodomicrobium vannielii, a member of the Rhodospirillaceae in which cell growth is obligately polar and cell division asymmetric, is a good experimental system for studying the regulation of cellular morphogenesis and differentiation. This organism can form three distinct cell types, the selective expression of which is environmentally induced. These are: ovoid cells joined by prosthecae, which may be branched so forming ramifying groups of cells; motile peritrichously flagellate swarmer cells; and unique, angular exospores (Whittenbury \& Dow, 1977).

During phototrophic batch culture of $R m$. vannielii the number of motile swarmer cells plateaus as the culture enters the late-exponential phase of growth (Dow \& France, 1980). The only limitation demonstrable during this phase of the growth cycle is that of low incident light intensity on a per cell basis as a consequence of cell shading. Under these conditions, the multicellular complexes continue to form and release swarmer cells but these do not initiate morphogenesis and differentiation, presumably due to the diminished ATP levels within the cell as a consequence of the low light intensity. Such a culture, which essentially consists of swarmer cells and multicellular complexes, can be easily and selectively synchronized by filtration (Whittenbury \& Dow, 1977). The filtrate contains primarily swarmer cells, routinely more than $97 \%$, which have not been subjected to physiological stress other than increasing light intensity per cell. This overcomes the initiation block and the swarmer cells enter the morphogenesis and differentiation cycle. With an incident light intensity of $5000 \mathrm{~lx}$ at $30^{\circ} \mathrm{C}$ the morphogenesis and differentiation cycle takes $6 \mathrm{~h}$ to completion (Fig. 1). This varies from experiment to experiment by up to $30 \mathrm{~min}$; however the cell cycle has a fixed relative temporal organization as does that of Caulobacter (Shapiro, 1976).

Incubated anaerobically in the light, selectively synchronized $R m$. vannielii swarmer cells develop through an obligate series of well defined stages which can be readily correlated with key biochemical and physiological events. Two of these are the loss of motility with the active shedding of the flagella (filament and hook) and the observation that DNA synthesis is a feature of the prosthecate reproductive cell only (Potts \& Dow, 1979). A similar situation is found in Caulobacter (Degnen \& Newton, 1972; Shapiro, 1976; Evinger \& Agabian, 1977), Rhodopseudo-

\footnotetext{
Abbreviations: NEPHGE, non-equilibrium pH gradient electrophoresis; TEMED, $N, N, N^{\prime}, N^{\prime}-$ tetramethylenediamine.
} 


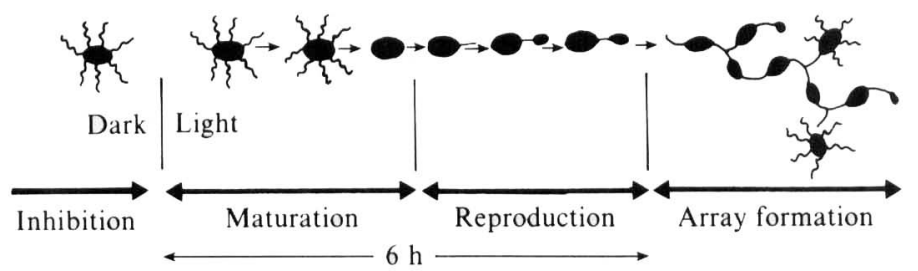

Fig. 1. Stages of the cell cycle during the differentiation of $R m$. vannielii swarmer cells.

monas palustris (Westmacott \& Primrose, 1977) and Hyphomicrobium (Wali et al., 1980). The obligate developmental sequence followed by the $R \mathbf{m}$. vannielii swarmer cell consists primarily of two phases: (a) maturation - the events leading from a motile swarmer cell to a sessile prosthecate cell which is fully competent with respect to reproduction (this phase occurs only once in the lifetime of any particular cell); (b) reproduction - the prosthecate cell is a fully functional reproductive unit which can repeat this phase with the sequential formation of several daughter cells.

In this paper, we report an $11.5 \mathrm{kDa}$ protein that is only synthesized under dark anaerobic conditions and is degraded when the culture is incubated anaerobically in the light. It is possible that the $11.5 \mathrm{kDa}$ protein acts as a cell differentiation inhibitor in $\mathrm{Rm}$. vannielii.

\section{METHODS}

Chemicals. Acrylamide, $N$ - $N^{\prime}$-methylenebisacrylamide and $N, N, N^{\prime}, N^{\prime}$-tetramethylenediamine (TEMED) were obtained from Eastman Kodak. Ampholines were purchased from LKB. Sodium pyruvate, L-methionine and Trizma base were purchased from Sigma; all other chemicals were from BDH. L-[35S]Methionine, specific activity ( $>600 \mathrm{Ci} \mathrm{mmol}^{-1} ;>22.2 \mathrm{TBq} \mathrm{mmol}^{-1}$ ) was purchased from Amersham.

Organism. Rhodomicrobium vannielii, strain RM5, from the culture collection at the Department of Biological Sciences, University of Warwick, was used throughout (Whittenbury \& Dow, 1977).

Cultural conditions. The growth medium contained $\left(\mathrm{g}^{-1}\right)$ : sodium pyruvate, 1.5 ; sodium hydrogen malate, 1.5; $\mathrm{NH}_{4} \mathrm{Cl}, 0.5 ; \mathrm{MgSO}_{4} .7 \mathrm{H}_{2} \mathrm{O}, 0.4 ; \mathrm{NaCl}, 0.4 ; \mathrm{CaCl}_{2}, 0.05$. The $\mathrm{pH}$ was adjusted to 6.8 with $\mathrm{KOH}$ prior to autoclaving and $50 \mathrm{ml} 0.1 \mathrm{M}-\mathrm{NaH}_{2} \mathrm{PO}_{4} / \mathrm{Na}_{2} \mathrm{HPO}_{4}$ buffer, $\mathrm{pH} \mathrm{6.8}$, was added aseptically after autoclaving. Starter cultures were grown in $250 \mathrm{ml}$ Quickfit conical flasks (B19/26), containing $100 \mathrm{ml}$ medium, which were fitted with Suba-seals (W. Freeman \& $\mathrm{Co}$.) and gassed with $\mathrm{O}_{2}$-free $\mathrm{N}_{2}$. These were incubated with shaking at $30^{\circ} \mathrm{C}$ with an incident light intensity (tungsten lamps) of approximately $3000 \mathrm{~lx}$. Large scale photoheterotrophic cultures were grown in 10 or 201 Quickfit culture vessels (FV10L, FV20L) fitted with multi-socket flat flange lids (MAF 2/2) and gassed with $\mathrm{O}_{2}$-free $\mathrm{N}_{2}$. Incubation was at $30^{\circ} \mathrm{C}$ with an incident light intensity of $5000 \mathrm{~lx}$ and with stirring.

Synchronization procedure. Photoheterotrophic batch cultures with an $\mathrm{OD}_{540}$ of 1.3-1.6, i.e. mid-late exponential phase, were examined microscopically and by cell volume distribution analysis to ascertain whether they were in the correct growth phase for selective synchronization, i.e. when swarmer cells had stopped differentiating and were accumulating in the culture. Homogeneous swarmer cell populations were subsequently obtained by the glass wool column technique of Whittenbury \& Dow (1977). These were incubated, with stirring, at $30^{\circ} \mathrm{C}$ under an $\mathrm{O}_{2}$-free $\mathrm{N}_{2}$ atmosphere and with an incident light intensity of $5000 \mathrm{~lx}$. The cultures were monitored at regular intervals by microscopy and cell volume distribution analysis. Samples taken during the course of an experiment were centrifuged $(15000 \mathrm{~g}, 15 \mathrm{~min})$, resuspended in a minimal volume of supernatant, immediately drop-frozen in liquid $\mathrm{N}_{2}$ and stored at $-20^{\circ} \mathrm{C}$ until required.

Cell volume distribution analysis. Cell volume distribution profiles were obtained using a ZBI Coulter Counter/ $\mathrm{Cl} 1000$ Channelyzer system interfaced to a Commodore 8032 microcomputer to facilitate data analysis and storage. The appropriate volume of sample was diluted in filtered electrolyte $(0.22 \mu \mathrm{m}$ membrane), so that the total count $\mathrm{ml}^{-1}$ was in the region of 3-6 $\times 10^{5}$. Analysis was performed using a $30 \mu \mathrm{m}$ orifice.

Incorporation of $\mathrm{L}-\left[{ }^{35}\right.$ S $]$ methionine into cell proteins. Samples $(100 \mathrm{ml})$ of synchronized cultures were labelled with $\mathrm{L}-\left[{ }^{35} S\right]$ methionine $\left(1 \mu \mathrm{Ci} \mathrm{ml}^{-1} ; 37 \mathrm{kBq} \mathrm{ml}^{-1}\right)$ for times and under conditions detailed in the figure legends. Further incorporation was stopped by the addition of unlabelled L-methionine to $1 \mathrm{mM}$. Cells were collected by centrifugation, drop-frozen in liquid nitrogen and stored at $-20^{\circ} \mathrm{C}$.

Preparation of soluble protein extracts. Cells, routinely stored at $-20^{\circ} \mathrm{C}$, were thawed, centrifuged $(15000 \mathrm{~g}$, $15 \mathrm{~min}$ ) and resuspended in a minimal volume of sonication buffer: $0.01 \mathrm{M}$-Tris/ $\mathrm{HCl}, \mathrm{pH} 7 \cdot 4 ; 5 \mathrm{mM}-\mathrm{MgCl}_{2} ; 50 \mu \mathrm{g}$ RNAase $\mathrm{ml}^{-1}$ (O'Farrell, 1975). The cells were sonicated for 10 periods at $15 \mathrm{~s}$ at $1 \mathrm{~min}$ intervals and cooled in an 


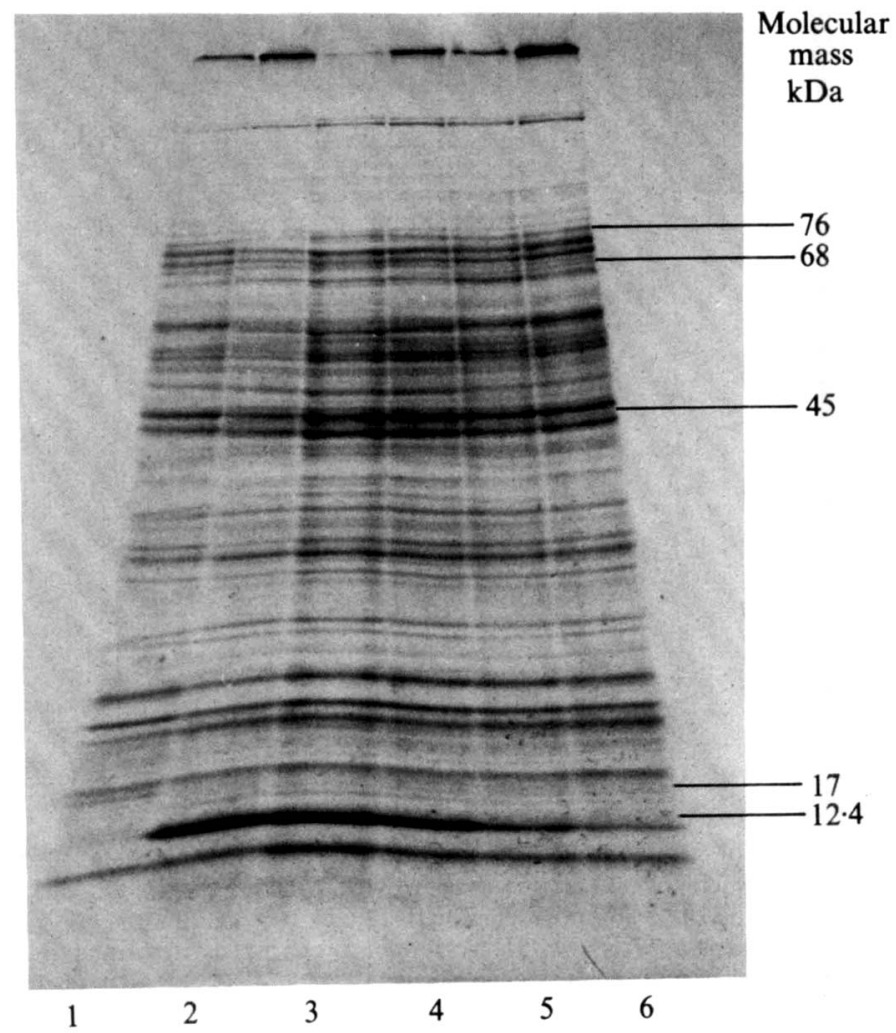

Fig. 2. Protein synthesis in swarmer cells maintained under different dark and light regimes. (1) Synchronized cells radiolabelled for $6 \mathrm{~h}$ in the light. Differentiation occurred yielding a fully grown daughter cell. (2) Synchronized cells radiolabelled for $6 \mathrm{~h}$ in the dark. Remained as swarmer cells. (3) Synchronized cells radiolabelled for $6 \mathrm{~h}$ in the dark plus $15 \mathrm{~min}$ in the light. Remained as swarmer cells. (4) Synchronized cells radiolabelled for $6 \mathrm{~h}$ in the dark plus $30 \mathrm{~min}$ in the light. Remained as swarmer cells. (5) Synchronized cells radiolabelled for $6 \mathrm{~h}$ in the dark plus $1 \mathrm{~h}$ in the light. Cells were non-motile but lacked prosthecae. (6) Synchronized cells radiolabelled for $6 \mathrm{~h}$ in the dark plus $2 \mathrm{~h}$ in the light. Cells attained the prosthecate stage. Swarmer cells were synchronized and $100 \mathrm{ml}$ samples labelled with $1 \mu \mathrm{Ci}$ $\mathrm{L}-\left[{ }^{35} \mathrm{~S}\right]$ methionine $\mathrm{ml}^{-1}$. Cell lysates were subjected to SDS-PAGE (10-30\% polyacrylamide) with 300000 c.p.m. labelled protein loaded per track, and autoradiographs were prepared.

ice/methanol freezing mixture. After sonication $50 \mu \mathrm{g} \mathrm{ml}^{-1}$ DNAase was added, and the sample was allowed to stand on ice for $15 \mathrm{~min}$ and then centrifuged $(15000 \mathrm{~g}, 15 \mathrm{~min})$. The supernatant fraction was used immediately and/or stored as samples at $-20^{\circ} \mathrm{C}$.

Determination of protein concentration. Proteins were determined using the Folin Phenol reagent according to Lowry with crystalline bovine serum albumin as standard.

$P A G E$. Discontinuous $10-30 \%(w / v)$ polyacrylamide concave gradient SDS gels were routinely used for onedimensional electrophoresis (Laemmli, 1970). The gels were cast between glass plates and the gradient prepared by pumping $10 \%$ acrylamide into a magnetically stirred vessel containing $20 \mathrm{ml} 30 \%$ acrylamide and $27 \%$ glycerol and the resulting mixture pumped to the gel plates. Polymerization was initiated by ammonium persulphate and TEMED. Electrophoresis was carried out at $4^{\circ} \mathrm{C}$ normally at $20 \mathrm{~mA}$ for $15 \mathrm{~h}$.

The NEPHGE system of two-dimensional electrophoresis was used with isoelectric focusing in the first dimension and discontinuous $10-30 \%$ polyacrylamide SDS gel in the second but was otherwise as described by O'Farrell et al. (1977).

Gels were stained in $0.1 \%(\mathrm{w} / \mathrm{v})$ Coomassie blue, $10 \%(\mathrm{v} / \mathrm{v})$ acetic acid, $45 \%(\mathrm{v} / \mathrm{v})$ methanol for not less than $4 \mathrm{~h}$ and destained in several changes of $10 \%$ acetic acid, $45 \%$ methanol. Gels were dried under vacuum onto $3 \mathrm{MM}$ chromatography paper on an $80^{\circ} \mathrm{C}$ water bath. Dried gels were exposed for up to several weeks to Kodak or Fuji X-ray films which were processed according to the manufacturer's instructions. Autoradiographs were photographed using background illumination on Kodak Panatomic X film. 

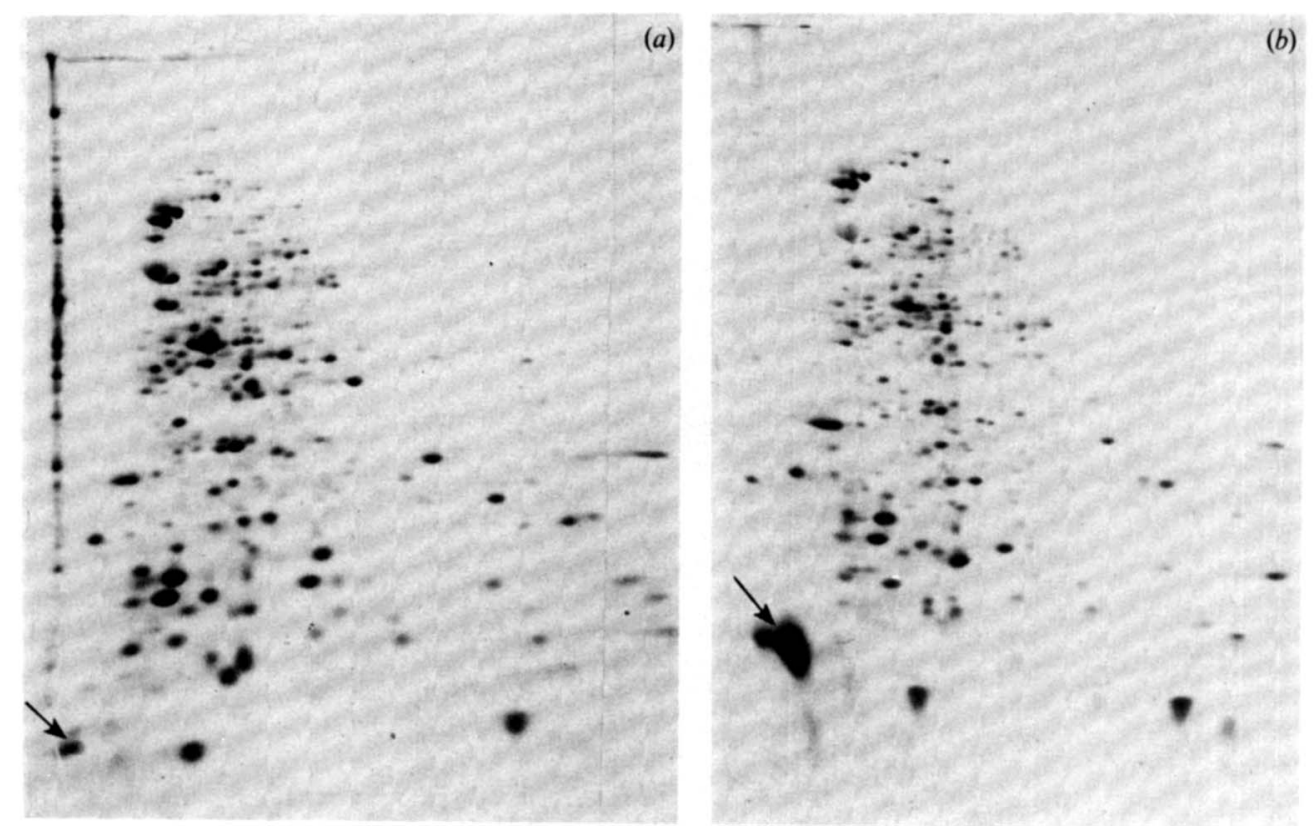

Fig. 3. Autoradiographs of two-dimensional NEPHGE gels of proteins radiolabelled under various regimes of light and dark. The $11.5 \mathrm{kDa}$ protein is arrowed. $(a) 6 \mathrm{~h}$ light; $(b) 6 \mathrm{~h}$ dark. Swarmer cells were synchronized, $100 \mathrm{ml}$ samples were labelled with $1 \mu \mathrm{Ci} \mathrm{L-}\left[{ }^{35} S\right]$ methionine $\mathrm{ml}^{-1}$; and cell lysates were prepared. Two-dimensional NEPHGE gels were prepared as described in Methods with 900000 c.p.m. ${ }^{35}$ S-labelled protein being loaded per gel.

\section{RESULTS AND DISCUSSION}

Protein synthesis in swarmer cells incubated under various regimes of light, dark and aerobicity

Swarmer cells were synchronized from a 3-d-old heterogeneous culture and $100 \mathrm{ml}$ samples labelled with $1 \mu \mathrm{Ci} \mathrm{L}-\left[{ }^{35} S\right]$ methionine $\mathrm{ml}^{-1}$ under different regimes of light and dark. Cell lysates were prepared and subjected to $10-30 \%$ SDS-PAGE, 300000 c.p.m. being loaded per track, and autoradiographs were prepared (Fig. 2). One protein, of molecular mass $11.5 \mathrm{kDa}$, was synthesized to a much greater extent under a dark regime. When a culture radiolabelled in the dark was exposed to light this protein began to be broken down after $30 \mathrm{~min}$ and was largely removed after $2 \mathrm{~h}$. Isolation of membranes and ribosomes from swarmer cells labelled with $\mathrm{L}$ ${ }^{[35}$ S $]$ methionine under dark and light regimes followed by SDS-PAGE showed that the $11.5 \mathrm{kDa}$ protein was not a membrane or ribosomal protein (data not shown), and thus it appears to be a soluble protein.

The cell lysates just described (Fig. 2) were also analysed by the two-dimensional NEPHGE system followed by autoradiography (Fig. 3). The $11.5 \mathrm{kDa}$ protein is acidic with a $\mathrm{pI}$ of 4.5 , which was confirmed by chromatofocussing. The patterns of protein synthesis in cells maintained under regimes of light and dark were very similar with the exception of the $11.5 \mathrm{kDa}$ protein. This similarity was shown both in one-dimensional SDS-PAGE and in the twodimensional NEPHGE system. About ten proteins could be recognized as being specific to, or mainly synthesized under, a light regime and three proteins including the $11.5 \mathrm{kDa}$ protein, were specifically synthesized under a dark regime. The differentiation of swarmer cells to produce a daughter cell which occurred under the light regime was accompanied by few differences in protein synthesis compared with that in non-differentiating swarmer cells under a dark regime. Changes in protein synthesis during differentiation could be seen using 10 min pulse labelling with $\mathrm{L}-\left[{ }^{35} \mathrm{~S}\right]$ methionine followed by SDS-PAGE and autoradiography of labelled proteins (data not shown) but these changes were only quantitative and no bands disappeared entirely. 


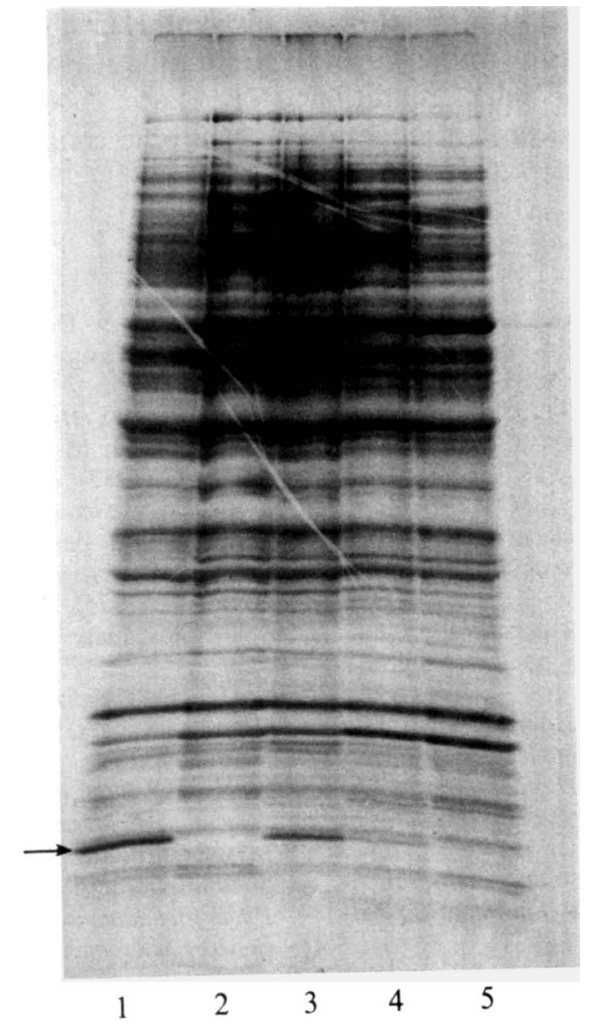

Fig. 4. Autoradiograph of 10-30\% polyacrylamide denaturing gel of proteins labelled in swarmer cells with $1 \mu \mathrm{Ci} \mathrm{L}-\left[{ }^{35} \mathrm{~S}\right]$ methionine $\mathrm{ml}^{-1}$ under various regimes of light and dark and aerobicity. The arrow indicates the $11.5 \mathrm{kDa}$ protein. (1) $6 \mathrm{~h}$ dark and anaerobic; (2) $6 \mathrm{~h}$ light and anaerobic; (3) $6 \mathrm{~h}$ dark and anaerobic plus $2 \mathrm{~h}$ dark and aerobic; (4) $6 \mathrm{~h}$ dark and aerobic; (5) $6 \mathrm{~h}$ dark and aerobic plus $2 \mathrm{~h}$ light and aerobic.

Cell lysates from swarmer cells incubated with $1 \mu \mathrm{Ci} \mathrm{m}^{-1} \mathrm{~L}-\left[{ }^{35} \mathrm{~S}\right]$ methionine under various regimes of light, dark and aerobicity were subjected to PAGE and autoradiography (Fig. 4). The $11.5 \mathrm{kDa}$ protein was synthesized only under dark anaerobic conditions (track 1) and its synthesis was abolished under dark aerobic conditions (track 4). The level of incorporation of radiolabel into the protein was reduced by a $2 \mathrm{~h}$ exposure to air (track 3 ). The $11.5 \mathrm{kDa}$ protein was degraded when the cells were exposed to aerobic conditions as well as light and it may have been that breakdown was controlled in some way by energy levels in the swarmer cell. The function of the $11.5 \mathrm{kDa}$ protein is unknown but its synthesis correlates with inhibition of differentiation in the light limited swarmer cell and its degradation coincides with the relief of that inhibition and consequent differentiation to produce a prosthecate reproductive cell.

When swarmer cells are incubated under dark anaerobic conditions they do not differentiate but remain as swarmer cells, losing viability only after $24 \mathrm{~h}$ (unpublished data). It appears that there is a block to the differentiation of swarmer cells (Fig. 1) that is overcome by incubation under anaerobic light conditions, suggesting an involvement of the energy state of the cell. How is this inhibited state of the cell maintained? In Escherichia coli there are proteins which are thought to be cell division inhibitors which are specifically degraded by the lon (capR) ATPhydrolysis-dependent protease (Mizusawa \& Gottesman, 1983; Schoemaker et al., 1982).

Proteins are synthesized in the swarmer cell when differentiation is inhibited by light limitation and although most of these are also synthesized in differentiating swarmer cells, a few, most notably an $11.5 \mathrm{kDa}$ protein, are specific to the inhibited state and may be involved in the maintenance of inhibition. More proteins are specific to growing cells and may be involved 
in cell differentiation. The $11.5 \mathrm{kDa}$ protein was only synthesized in $R m$. vannielii swarmer cells under light limitation and was degraded when the limitation was removed or if the culture was incubated aerobically under dark conditions. The latter observation suggests that the accumulation of the $11.5 \mathrm{kDa}$ protein under dark anaerobic conditions is not connected with photosynthesis, but its function is at present speculative.

\section{REFERENCES}

Degnen, S. T. \& Newton, A. (1972). Chromosome replication during development in Caulobacter crescentus. Journal of Molecular Biology 64, 671-680.

Dow, C. S. \& France, A. D. (1980). Simplified vegetative cell cycle of Rhodomicrobium vannielii. Journal of General Microbiology 117, 47-55.

Evinger, M. \& Agabian, N. (1977). Envelopeassociated nucleoid from Caulobacter crescentus stalked and swarmer cells. Journal of Bacteriology 132, 294-301.

LAEMMLI, U. K. (1970). Cleavage of structural proteins during the assembly of the head of bacteriophage T4. Nature, London 227, 680-685.

Mizusawa, S. \& Gottesman, S. (1983). Protein degradation in Escherichia coli: the lon gene controls the stability of sulA protein. Proceedings of the National Academy of Sciences of the United States of America 80, 358-362.

O'FARRELL, P. H. (1975). High resolution two-dimensional electrophoresis of proteins. Journal of Biological Chemistry 250, 4007-4021.

O'Farrell, P. Z., GoOdman, H. M. \& O'FARrell, P. H. (1977). High resolution two-dimensional electrophoresis of basic as well as acidic proteins Cell 12, 1133-1142.
PorTS, L. E. \& Dow, C. S. (1979). Nucleic acid synthesis during the developmental cycle of the Rhomomicrobium vannielii swarmer cell. FEMS Microbiology Letters 6, 393-395.

Schoemaker, J. M., Henderson, G. W. \& MarkovITZ, A. (1982). Escherichia coli polypeptide controlled by the lon (capR) ATP hydrolysis dependent protease and possibly involved in cell division. Journal of Bacteriology 152, 919-923.

ShapIRo, L. (1976). Differentiation in the Caulobacter cell cycle. Annual Review of Microbiology 30, 377407.

Wali, T. M., Hudson, G. R., Donald, D. A. \& WEINER, R. M. (1980). Timing of swarmer cell cycle morphogenesis and macromolecular synthesis by Hyphomicrobium neptunium in synchronous culture. Journal of Bacteriology 144, 406-412.

Westmacott, D. \& Primrose, S. B. (1977). The effect of nalidixic acid on the cell cycle of synchronous Rhodopseudomonas palustris cultures. Journal of General Microbiology 98, 155-166.

WhITTENBURY, R. \& Dow, C. S. (1977). Morphogenesis and differentiation in Rhodomicrobium vannielii and other budding and prosthecate bacteria. Bacteriological Reviews 41, 754-808. 